\title{
Peer- Coaching, EFL Teacher's Professional Identity Development and Students' Academic Achievements
}

\author{
Gholam-Reza Abbasian \\ Universities of Imam Ali \& IA (South Tehran), Iran \\ Matin Karbalaee Esmailee \\ Alborz Higher Education Centre, Iran
}

\begin{abstract}
The purpose of this study was two-fold: examining the effect of peer coaching on EFL teachers' professional identity and learners' academic achievement. To this end, this very mixed-methods research was designed to see the extent to which the least investigated variable in the Iranian EFL setting. Five high school RFL teachers were triangularly coached and achievements of their classes including those of 307 EFL students were investigated. The teachers received questionnaire both before and after a 12-session coaching process while being both observed and attended a think-aloud protocol reporting. Moreover, the standardized Classroom Observation Sheet was employed whilst the coaching process. The students' entry and exit academic behaviours in terms of achievements were measured prior to and after the treatment. Analyses of each set of data collected from each group indicated that peer coaching entailed statistically significant developments in many categories teachers' professional identity as well as in the students' academic achievements.Pedagogically, the findings suggest feasibility and effectiveness of conducting peer-coaching and internalizing it in our EFL educational system.
\end{abstract}

Index Terms - teachers' professional development, peer-coaching, academic achievements

\section{INTRODUCTION}

Teachers' professional development has recently received prime attention. In contrast to the traditional methods of teaching being based on some one-shot training, nowadays most methods focus on the enhancement of teachers' skills, competencies and practices. Among such teaching mechanisms, peer coaching is claimed to enable teachers to exchange support, feedback, and assistance (Ackland, 1991). According to Reiman and Johnson (2003), peer coaching can maximize creativity among teachers and develop a disposition of collaboration and continuous improvement; a path which can ultimately to teacher's professional development.

In the past, professional development was left up on to outside providers who used to intervene through short-term events like one-day workshops (Rainville, 2007). But nowadays, the researches argue that professional development requires some factors to be more effective: it must be based on specific context, sustained over time, and connected to teachers' daily practice, and be collaborative (Cochran-Smith \& Lytle, 2001; Garet, Porter, Desimone, Birman, \& Yoon, 2001; Neufeld \& Roper, 2003a, 2003b).

As an emerging concept, teacher's "professional identity has become a new area of research in education (Clarke, Hyde, \& Jonathan, 2013). According to Epstein (1978), professional identity is essentially an integrative concept that "represents the process by which the person seeks to integrate his various statuses and roles, as well as his diverse experiences into a coherent image of self" (p. 101). Beijaard et al. (2004) hold it provides the basis for "decision making and meaning making on the part of teachers" (p.109). It fosters teacher's creativity and autonomy (Singh \& Richards, 2006), facilitates achievements of transformative goals (Cochran-Smith \& Lytle, 2001), and plays a more significant role in teaching quality (Clandinin \& Connelly, 1996, Beijaard et al., 2004). Lasky (2005) refers to professional identity as how teachers define themselves as teachers: e.g., answering such major questions as "who am I?", "what kind of teacher do I want to be?", and "how do I see my role as a teacher?"(Korthagen, 2004, p. 81). Vakili (2010) schematizes his own understanding of how the teacher self is constructed and also how teachers shape their selves as language teachers. 


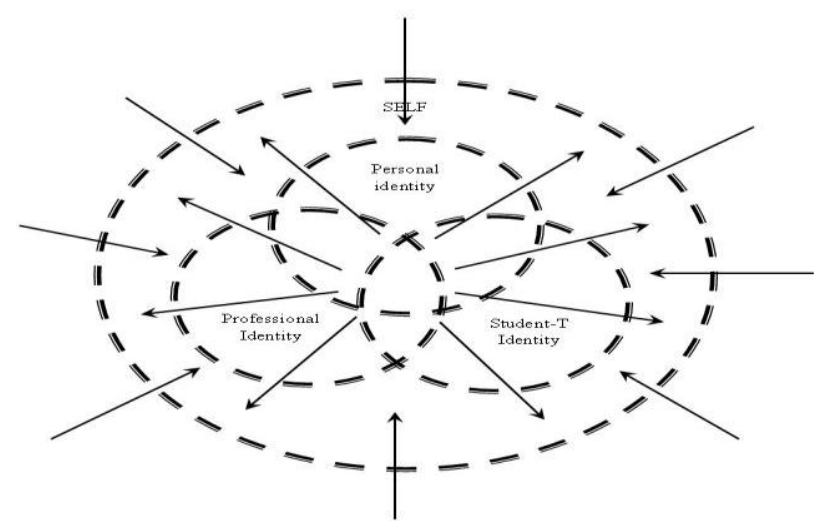

Fig. 1. Schematic Representation of the Teacher Self.(Vakili 2010)

\section{A. Coaching}

One of supposedly supported channels of developing a sense of cooperation among teachers is coaching, which is not only a "role with a job description that one person carries out in a school", but also it is a "strategic, systemic approach to improving student learning" (Saphier \& West, 2009, p. 47). Sherri (2010) considers coaching as assistance for which addresses "assessment of language, and complex challenges to learning, teaching and also through a process of inquiry that is co-constructed and dialogic, opens teachers through self-critical, exploratory, and reflective dimensions of interaction" (p. 1).

Coaching is named differently including "peer mentoring, learning-centered supervision, peer supervision, and cognitive coaching" (Pellicer and Anderson, cited in Britton, 2006, p .8) and introduced under various categories in developing organizational behavior such as "cognitive coaching, instructional coaching and peer coaching" (Beglau et al., 2011, p. 9). Similarly, four predominant types of coaching models are predominant in education including "peer coaching, cognitive coaching, literacy coaching, and instructional coaching” (Cornett \& Knight, 2009, p. 196).

\section{B. Peer Coaching}

According to Neubert and McAllister (1993), peer coaching is the collaboration between two colleagues, which involves teachers in collaborative procedure that helps them to apply new instructional practices, curricula (Shower, 1982), and skills learned in workshop (Galbraith \& Anstrom, 1995). Moreover, Huston and Weaver (2008) discussed peer coaching as a "collegial process whereby two faculty members voluntarily work together to improve or expand their approaches to teaching" (p.19). This kind of coaching focuses on observation, feedback and planning in collaborative way to improve new instructional technique and curriculum (Ackland, 1991; Odell, 1990; Perkins, 1998). Peer coaching is based on a number of principles identified by Robertson (2005) as follows:

- Trust: facilitates adult learning (Fielding et al., 2005; Ladyshewsky, 2006).

- Collaboration: is always relevant to growth and improvement of classroom teacher (Robertson, 2008; Ladyshewsky, 2006; Briton \& Anderson, 2010).

- Conferencing: gives parents opportunity to receive feedback before and after instruction (Costa \& Garmson, 2002).

- Analysis and reflection: helps the learner to process the data, alter practices, and build efficacy, self-assessment, develop a professional culture, identify issues, deepen understanding, and challenge ideas (Robertson, 2008).

\section{Problem and Purpose}

Contrary to the numerous studies conducted on both variables separately, there seems ample room for further studies on investigating the effects of peer-coaching not only on professional identity development (PID) of the target teachers but also on the students' English language academic achievements. In order to fill such a gap in the literature, the study pursues two specific objectives: to investigate the extent to which the Iranian EFL teachers' professional identity could be a function of coaching, and to examine possible improvements in EFL learners' academic achievements in light of further professional development. To this end, the following research questions followed up in the form of respective hypotheses were raised:

1. Does peer coaching have any significant effects on professional identity development of Iranian high school EFL teachers?

2. Does peer coaching have any significant effects on Iranian high school EFL students' academic achievements?

\section{METHODS}

\section{A. Participants}


Participants were five EFL female teachers and 307 Iranian students from five different high schools. The teachers' teaching experience ranged from ten to fifteen years. The students were divided into two groups: one experimental and one control. The experimental group consisted of 156 but the control group included 151 students.

\section{B. Instrumentation}

To conduct this study, the following instruments were employed:

1. Nelson Test: as a general proficiency test used to select a homogeneous sample of EFL learners.

2. Researcher-made Diagnostic Test: to measure the learners' entry behavior respectively prior to the treatment.

3. A Researcher-made Achievement Test: was designed to measure the learners' exit behavior after the treatment.

4. Teacher Professional Identity Development Questionnaire: was used to measure the teachers' professional development level both before and after the coaching, as already used for similar purpose (Douwe, Beijaard, NicoVerloop, Jan D. Vermont, 1999).

5. Classroom Observation Sheet: Developed by Eugene Schaffer, Daniel Muijs, Catherine Kitson, David Reynolds, was used to record the report of coaching and teachers' professional development.

\section{Procedure}

The participating teachers were randomly selected and in coordination with the authorities of each school, they were encouraged to cooperate with the researchers. Each teacher used to manage one class with three hours and 30 minutes of the teaching during a week held in for two sessions per week.

Following a formal briefing session, they completed the PID Questionnaire prior to the coaching process. They also participated in a pre-observation conference thereby they shared their class and syllabus details and lesson plan. They were coached and observed for 15 sessions by one of the researchers. During the observation, the coach would watch for specific teaching and learning behaviors and record them in details. She would monitor the teachers' classroom conduct in implementing the syllabus. Furthermore, the teachers and coach had post-observation conference to talk about the classroom conduct, each of which was followed by constructive feedback. Finally, the PID Questionnaire was administered again to measure any developments in order to compare pre- and post- behavior.

As to the students, the Nelson Test and Diagnostic Test were administered to select a homogeneous group of learners and to measure the learners' entry behavior, respectively. Ultimately, the Achievement Test was administered to measure the learners' academic achievements.

\section{RESUlTS AND DiSCUSSION}

\section{A. Investigation of the Research Question One}

The Mann-Whitney U test was run to compare the experimental and control groups' professional identity prior to the coaching process. As displayed in Table 1 , the mean ranks for the experimental $(\mathrm{M}=6.80)$ group showed a higher mean rank than that of the control $(\mathrm{M}=4.20)$ group.

TABLE. 1.

MEAN RANKS; PRETEST OF PROFESSIONAL IDENTITY BY GROUP

\begin{tabular}{lllll}
\hline & Group & N & Mean Rank & Sum of Ranks \\
\hline \multirow{3}{*}{ Pretest } & Experimental & 5 & 6.80 & 34.00 \\
& Control & 5 & 4.20 & 21.00 \\
& Total & 10 & & \\
\hline
\end{tabular}

The results of the Mann-Whitney $U$ test $(U=6, Z=-1.36, P>.05)$ indicated that the pre-coaching difference between the two mean ranks observed in Table 2 was no significant.

TABLE. 2.

MANN-WHiTnEY U TEST STATISTICS

\begin{tabular}{ll}
\hline & Pretest \\
\hline Mann-Whitney U & 6.000 \\
Wilcoxon W & 21.000 \\
$Z$ & -1.362 \\
\hline Asymp. Sig. (2-tailed) & .173 \\
Exact Sig. [2*(1-tailed Sig.)] & $.222^{\text {b }}$ \\
\hline a. Grouping Variable: Group & \\
b. Not corrected for ties. &
\end{tabular}

However, the Mann-Whitney U test run after the coaching, as displayed in Table 3, shows the mean rank for the experimental $(\mathrm{M}=8.00)$ group is higher than that of the control $(\mathrm{M}=3.00)$ group. 
TABLE. 3.

MEAN RANKS; POSTTEST OF PROFESSIONAL IDENTITY BY GROUP

\begin{tabular}{lllll}
\hline & Group & $\mathrm{N}$ & Mean Rank & Sum of Ranks \\
\hline \multirow{3}{*}{ Posttest } & Experimental & 5 & 8.00 & 40.00 \\
& Control & 5 & 3.00 & 15.00 \\
& Total & 10 & & \\
\hline
\end{tabular}

So, based on the results of the Mann-Whitney $\mathrm{U}$ test $(\mathrm{U}=6, \mathrm{Z}=-2.61, \mathrm{P}<.05)$ there was significant difference between the experimental and control groups' mean ranks as shown in Table 4. Thus, it can be concluded that the first null-hypothesis was rejected.

TABLE. 4.

MANN-WHitNEY U TEST STATISTICS

\begin{tabular}{ll}
\hline & Posttest \\
\hline Mann-Whitney U & .000 \\
Wilcoxon W & 15.000 \\
$\mathrm{Z}$ & -2.619 \\
\hline Asymp. Sig. (2-tailed) & .009 \\
Exact Sig. [2*(1-tailed Sig.)] & $.008^{\mathrm{b}}$ \\
\hline a. Grouping Variable: Group & \\
b. Not corrected for ties. &
\end{tabular}

\section{Observation.}

The attending teachers were also observed and their trend of their professional development on the following seven performance categories was recorded:

- Class management,

- Classroom behavior,

- Focusing and maintaining attention,

- Review and practice,

- Questioning skills,

- Teaching skills, and

- Positive classroom climate.

The observation data were also analyzed through both descriptive and inferential statistics (MANAOVA) for each individual teacher.

\section{Comparing Teachers' Performance.}

Graph 1 numerically illustrates the whole picture of the means of the performance of the attending teachers on the seven categories of the professional development.

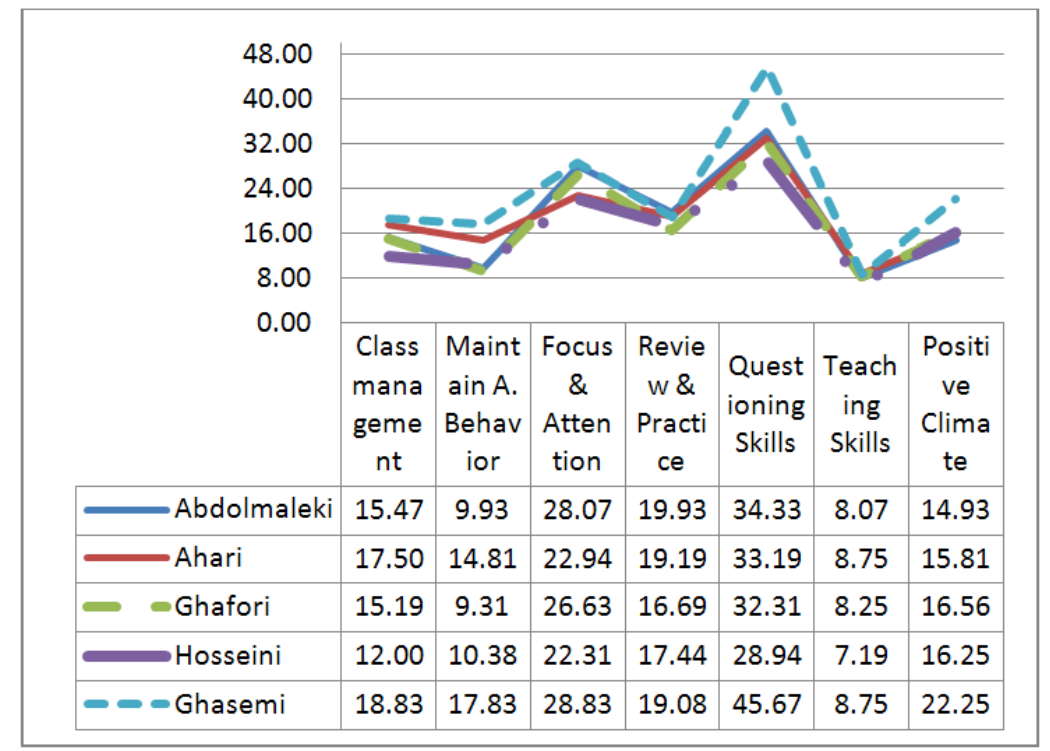

Graph. 1. Classroom Activities by Teachers

Trends of Teachers' Performance over Sessions.

What follows, displays the participants' classroom conduct as represented in the seven categories over the 15-session of coaching process recorded based on the observation sheet.

Maintaining Classroom Management. 
Graph 2 shows that classroom management being at the lowest level on the first session, gradually increased to its highest level on fourth session and had an almost even trend until it showed a large decrease on the eleventh session. It began to increase after the major decrease and showed an almost upward move before the last decrease on the last session. It seems that the classroom management is maintained the teachers felt downward movement.

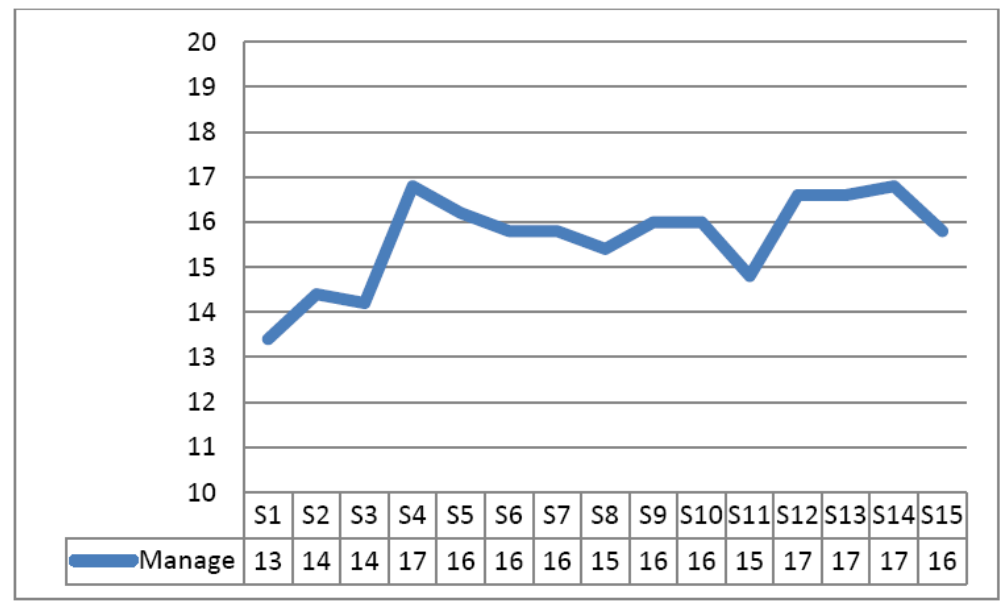

Graph. 2. Maintaining Classroom Management over 15 Sessions

Maintaining Appropriate Classroom Behavior.

Graph 3 shows that appropriate classroom behavior showed an increasing trend over the first three sessions after which a major decrease happened. Then, it increased and showed an almost steady pattern before the highest increase on the twelfth session.

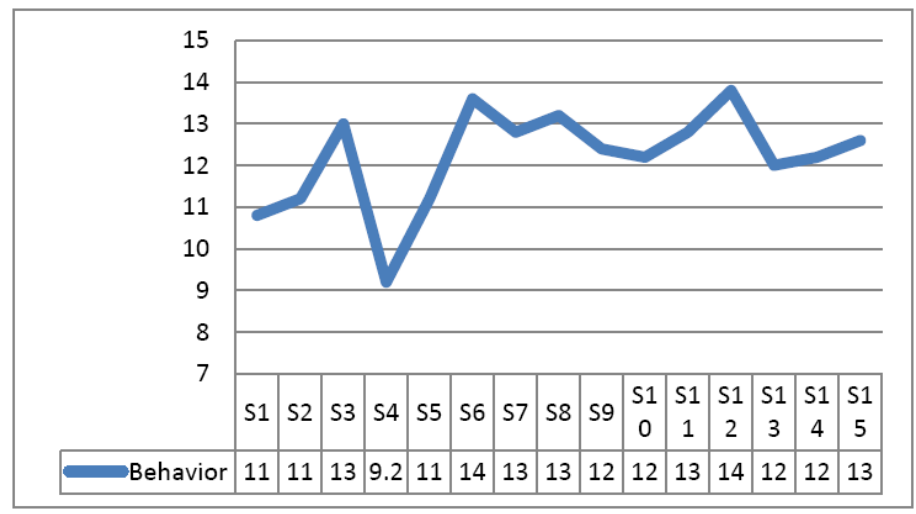

Graph. 3. Maintaining Appropriate Classroom Behavior

Focus and Maintain Attention.

Graph 4 shows that focusing and maintaining attention on lesson had a rising-and-falling pattern every two or three sessions. It started to move upward on the first three sessions then showed the biggest fall.

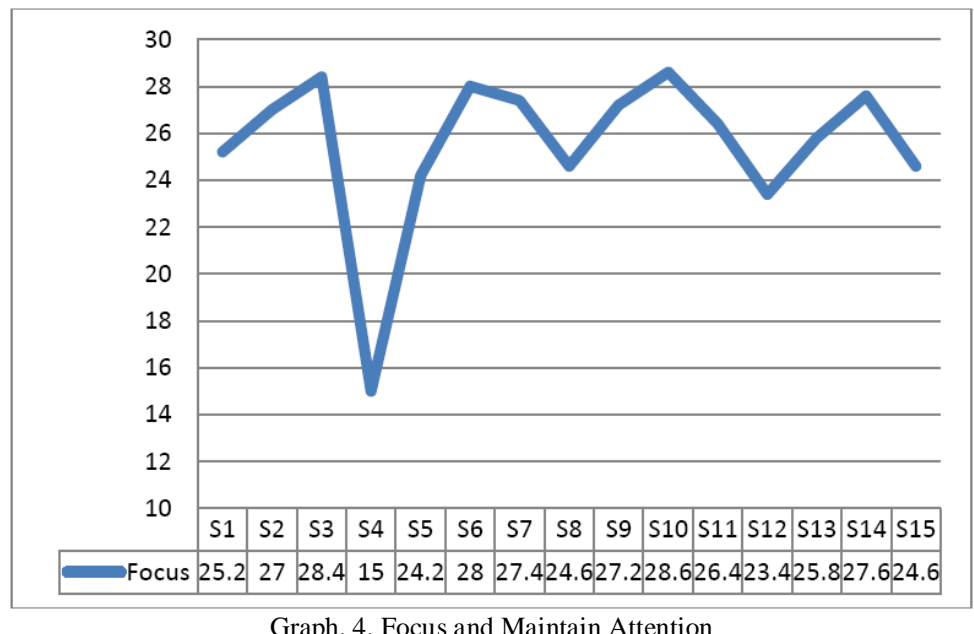


Providing Students with Review and Practice.

Graph 5 shows teachers provided students with review and practice every other session; with the highest and lowest reviews on the third and fourth sessions, respectively.

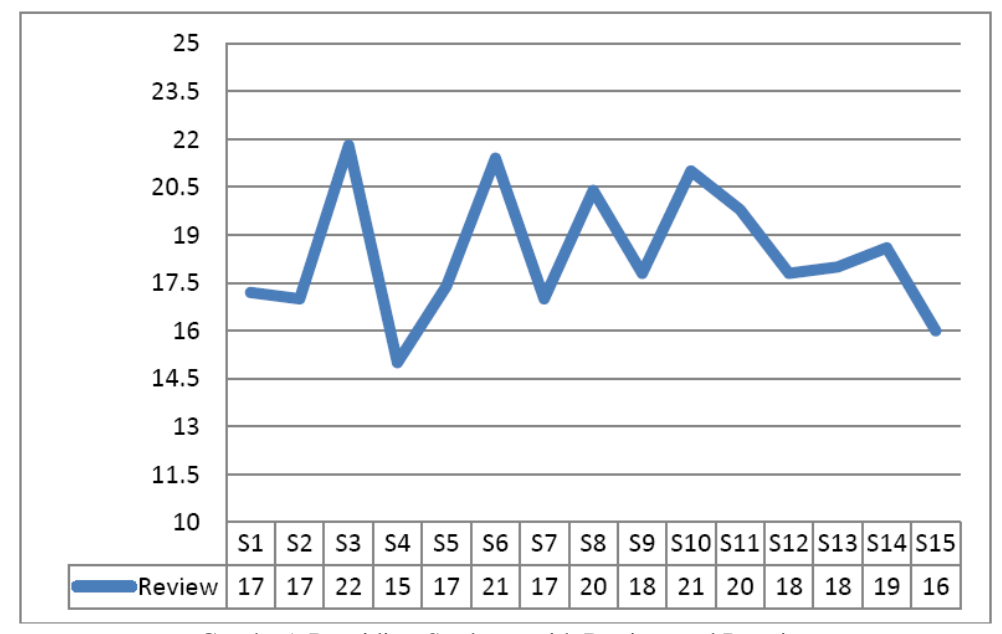

Graph. 5. Providing Students with Review and Practice

Demonstrating Questioning Skills.

Graph 6 shows that teachers did not hold a clear pattern when demonstrating questioning skills. It showed a risingand-falling pattern over the session with the lowest and highest at fourth and thirteenth sessions, respectively.

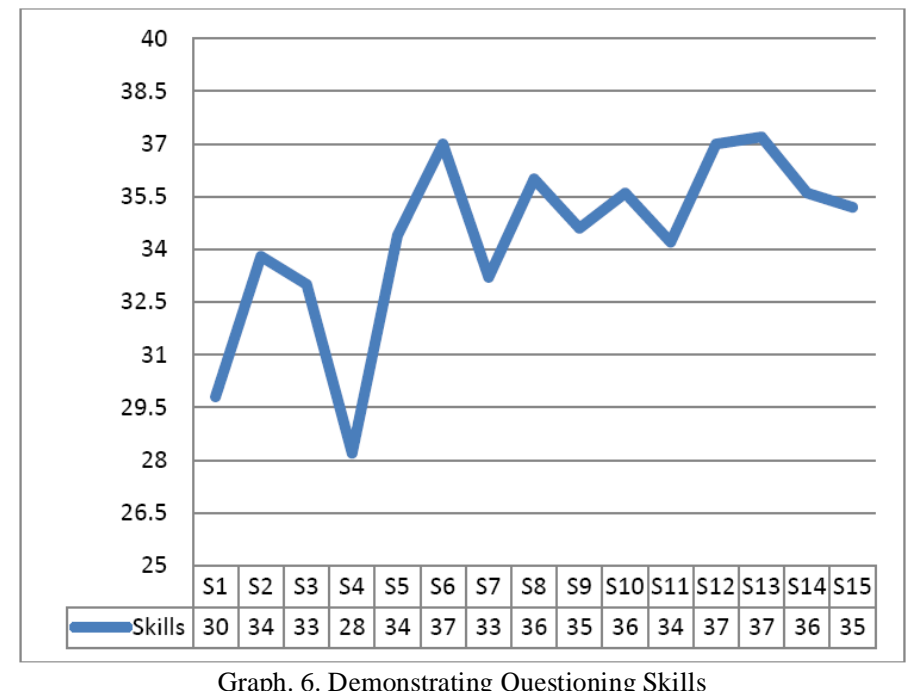

Demonstrating a Variety of Teaching Methods.

Graph 7 shows that teachers showed an almost steady pattern during the first two sessions ending in a sharp decline in the fourth session. Then, they moved up using variations in teaching followed by downward movement and got to their highest point in the tenth session and finally ended in a falling trend. 


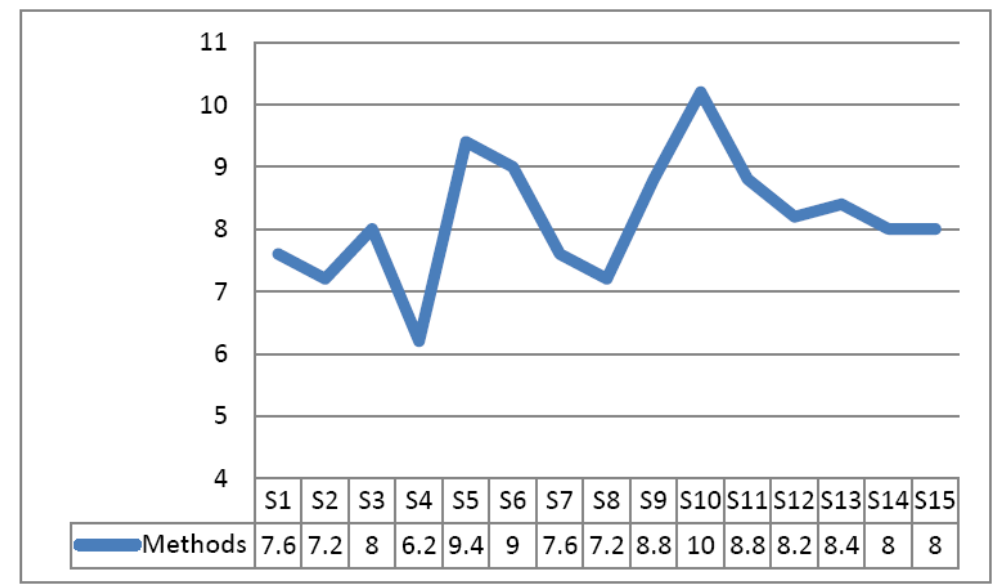

Graph. 7. Demonstrating a Variety of Teaching Methods

\section{Establishing a Positive Classroom Climate.}

The first three sessions witnessed a rising pattern for establishing a positive climate in classroom which was followed by a sharp decline. A curve pattern followed with two sharp falling then rising patterns.

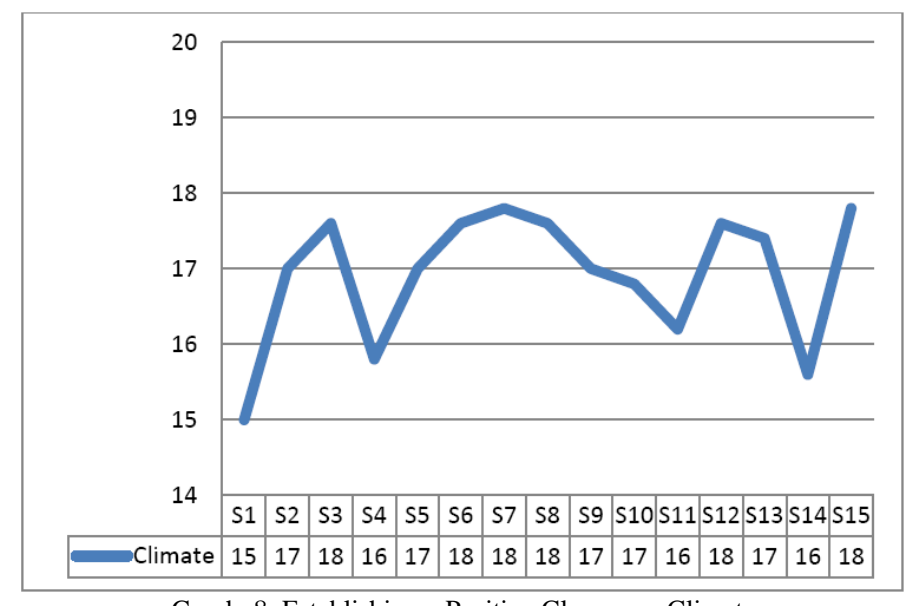

Graph. 8. Establishing a Positive Classroom Climate

Along with the figures and graphs, multivariate ANOVA (MANOV) was run to compare the teachers' application of the seven teaching techniques. As displayed in Table 5, the probabilities associated with the Levene's F-values were all higher than .05. Thus, the assumption of homogeneity of variances was met.

TABLE. 5.

LEVENE'S TEST OF EQUALITY OF ERROR VARIANCES

\begin{tabular}{lllll}
\multicolumn{5}{c}{ LEVENE'S TEST OF EQUALITY OF ERROR VARIANCES } \\
\hline & $\mathrm{F}$ & $\mathrm{df1}$ & $\mathrm{df} 2$ & Sig. \\
\hline Class Management & 2.022 & 4 & 70 & .101 \\
Maintain Behavior & 2.120 & 4 & 70 & .087 \\
Focus \& Attention & 1.275 & 4 & 70 & .288 \\
Review \& Practice & .655 & 4 & 70 & .625 \\
Questioning Skills & 2.091 & 4 & 70 & .091 \\
Teaching Skills & .205 & 4 & 70 & .935 \\
Positive Climate & 1.964 & 4 & 70 & .110 \\
\hline
\end{tabular}

The main results are discussed referring to the following three tables: 5 which shows the F-values, 6 showing the descriptive statistics and 7 which shows the results of the post-hoc Scheffe's tests.

Maintaining Classroom Management.

Based on the results displayed in tables 5, 6 and 7, there were significant differences between the five teachers' maintenance of classroom management $\left(\mathrm{F}(4,70)=11.44, \mathrm{P}<.05\right.$, Partial $\eta^{2}=.39$ representing a large effect size $)$. The means scores in order of magnitude were; Ghasemi $(M=18.83)$, Ahari $(M=17.50)$, Abdoulmaleki $(M=15.46)$, Ghafori $(M=15.18)$ and Hosseini $(M=12)$. The results of the post-hoc Scheffe's tests (table 7) indicate that there were four significant differences among the means.

A.1: Ghasemi $(M=18.83)$ showed a significantly higher mean on maintenance of classroom management than Hosseini $(\mathrm{M}=12)(\mathrm{M}=6.83, \mathrm{P}<.05)$ and Ghafori $(\mathrm{M}=15.18)(\mathrm{M}=3.65, \mathrm{P}<.05)$, did.

A.2: Ahari $(\mathrm{M}=17.50)$ showed a significantly higher mean on maintenance of classroom management than Hosseini $(\mathrm{M}=12)(\mathrm{MD}=5.50, \mathrm{P}<.05)$, did. 
TABLE. 6.

TESTS OF BETWEEN-SUBJECTS EFFECTS

\begin{tabular}{llllll}
\hline Source & Dependent Variable & df & F & Sig. & Partial Eta Squared \\
\hline \multirow{5}{*}{ Teachers } & Classmang & 4 & 11.440 & .000 & .395 \\
& Maintbeh & 4 & 21.268 & .000 & .549 \\
& Focus & 4 & 2.891 & .028 & .142 \\
& Review & 4 & 1.271 & .290 & .068 \\
& Demoskill & 4 & 10.914 & .000 & .384 \\
& Demomethod & 4 & 1.295 & .281 & .069 \\
& Positclim & 4 & 10.447 & .000 & .374 \\
\hline
\end{tabular}

A.3: Abdoulmaleki $(\mathrm{M}=15.46)$ showed a significantly higher mean on maintenance of classroom management than Hosseini $(\mathrm{M}=12)(\mathrm{MD}=3.47, \mathrm{P}<.05)$, did.

\section{Maintaining Appropriate Classroom Behavior.}

Based on the results displayed in tables 5, 6, and 7, there were significant differences between the five teachers' maintenance of appropriate classroom behavior $\left(\mathrm{F}(4,70)=21.26, \mathrm{P}<.05\right.$, Partial $\eta^{2}=.54$ representing a large effect size). The means scores in order of magnitude were; Ghasemi $(M=17.83)$, Ahari $(M=14.81)$, Hosseini $(M=10.37)$, Abdoulmaleki $(M=9.93)$ and Ghafori $(M=9.31)$. The results of the post-hoc Scheffe's tests indicated that there were five significant differences between the means.

A.1: Ghasemi $(\mathrm{M}=17.83)$ showed a significantly higher mean on maintenance of appropriate classroom behavior than Abdoulmaleki $(\mathrm{M}=9.93)(\mathrm{M}=7.90, \mathrm{P}<.05)$, Ghafori $(\mathrm{M}=9.31)(\mathrm{M}=8.52, \mathrm{P}<.05)$ and Hosseini $(\mathrm{M}=10.37)$ $(\mathrm{M}=7.46, \mathrm{P}<.05)$, did.

A.2: Ahari $(\mathrm{M}=14.81)$ showed a significantly higher mean on maintenance of appropriate classroom behavior than Ghafori $(\mathrm{M}=9.31)(\mathrm{M}=5.50, \mathrm{P}<.05)$, Abdoulmaleki $(\mathrm{M}=9.93)(\mathrm{M}=4.88, \mathrm{P}<.05)$ and Hosseini $(\mathrm{M}=10.37)(\mathrm{M}=$ $4.44, \mathrm{P}<.05)$, did.

TABLE. 7.

SCHEFFE'S MULTIPLE COMPARISONS

\begin{tabular}{|c|c|c|c|c|}
\hline Dependent Vari & (I) Teachers & (J) Teachers & $\begin{array}{l}\text { Mean Difference } \\
(\mathrm{I}-\mathrm{J})\end{array}$ & Sig. \\
\hline \multirow{20}{*}{ Class-manage } & \multirow{4}{*}{ Abdoulmalek } & Ahari & -2.03 & .451 \\
\hline & & Ghafori & .28 & .999 \\
\hline & & ${ }^{1}$ Hosseini & $3.47^{*}$ & .037 \\
\hline & & Ghasemi & -3.37 & .078 \\
\hline & \multirow{4}{*}{ Ahari } & Abdoulmaleki & 2.03 & .451 \\
\hline & & Ghafori & 2.31 & .300 \\
\hline & & Hosseini & $5.50^{*}$ & .000 \\
\hline & & Ghasemi & -1.33 & .840 \\
\hline & \multirow{4}{*}{ Ghafori } & Abdoulmaleki & -.28 & .999 \\
\hline & & Ahari & -2.31 & .300 \\
\hline & & Hosseini & 3.19 & .061 \\
\hline & & Ghasemi & $-3.65^{*}$ & .040 \\
\hline & \multirow{4}{*}{ Hosseini } & Abdoulmaleki & $-3.47^{*}$ & .037 \\
\hline & & Ahari & $-5.50^{*}$ & .000 \\
\hline & & Ghafori & -3.19 & .061 \\
\hline & & Ghasemi & $-6.83^{*}$ & .000 \\
\hline & \multirow{4}{*}{ Ghasemi } & Abdoulmaleki & 3.37 & .078 \\
\hline & & Ahari & 1.33 & .840 \\
\hline & & Ghafori & $3.65^{*}$ & .040 \\
\hline & & Hosseini & $6.83^{*}$ & .000 \\
\hline \multirow{16}{*}{ Maintin-behav } & \multirow{4}{*}{ Abdoulmaleki } & Ahari & $-4.88^{*}$ & .001 \\
\hline & & Ghafouri & .62 & .987 \\
\hline & & Hosseini & -.44 & .996 \\
\hline & & Ghasemi & $-7.90^{*}$ & .000 \\
\hline & \multirow{4}{*}{ Ahari } & Abdoulmaleki & $4.88^{*}$ & .001 \\
\hline & & Ghafori & $5.50^{*}$ & .000 \\
\hline & & Hosseini & $4.44^{*}$ & .003 \\
\hline & & Ghasemi & -3.02 & .146 \\
\hline & \multirow{4}{*}{ Ghafori } & Abdoulmaleki & -.62 & .987 \\
\hline & & Ahari & $-5.50^{*}$ & .000 \\
\hline & & Hosseini & -1.06 & .906 \\
\hline & & Ghasemi & $-8.52^{*}$ & .000 \\
\hline & \multirow{4}{*}{ Hosseini } & Abdoulmaleki & .44 & .996 \\
\hline & & Ahari & $-4.44^{*}$ & .003 \\
\hline & & Ghafori & 1.06 & .906 \\
\hline & & Ghasemi & $-7.46^{*}$ & .000 \\
\hline
\end{tabular}




\begin{tabular}{|c|c|c|c|c|}
\hline & \multirow{4}{*}{ Ghasemi } & Abdoulmaleki & $7.90^{*}$ & .000 \\
\hline & & Ahari & 3.02 & .146 \\
\hline & & Ghafori & $8.52^{*}$ & .000 \\
\hline & & Hosseini & $7.46^{*}$ & .000 \\
\hline \multirow{20}{*}{ Focus } & \multirow{4}{*}{ Abdoulmaleki } & Ahari & 5.13 & .348 \\
\hline & & Ghafori & 1.44 & .985 \\
\hline & & ${ }^{1}$ Hosseini & 5.75 & .235 \\
\hline & & Ghasemi & -.77 & .999 \\
\hline & \multirow{4}{*}{ Ahari } & Abdoulmaleki & -5.13 & .348 \\
\hline & & Ghafori & -3.69 & .660 \\
\hline & & Hosseini & .63 & .999 \\
\hline & & Ghasemi & -5.90 & .269 \\
\hline & \multirow{4}{*}{ Ghafori } & Abdoulmaleki & -1.44 & .985 \\
\hline & & Ahari & 3.69 & .660 \\
\hline & & Hosseini & 4.31 & .512 \\
\hline & & Ghasemi & -2.21 & .945 \\
\hline & \multirow{4}{*}{ Hosseini } & Abdoulmaleki & -5.75 & .235 \\
\hline & & Ahari & -.63 & .999 \\
\hline & & Ghafori & -4.31 & .512 \\
\hline & & Ghasemi & -6.52 & .178 \\
\hline & \multirow{4}{*}{ Ghasemi } & Abdoulmaleki & .77 & .999 \\
\hline & & Ahari & 5.90 & .269 \\
\hline & & Ghafori & 2.21 & .945 \\
\hline & & Hosseini & 6.52 & .178 \\
\hline \multirow{20}{*}{ Review } & \multirow{4}{*}{ Abdoulmaleki } & Ahari & .75 & .995 \\
\hline & & Ghafori & 3.25 & .457 \\
\hline & & Hosseini & 2.50 & .704 \\
\hline & & Ghasemi & .85 & .994 \\
\hline & \multirow{4}{*}{ Ahari } & Abdoulmaleki & -.75 & .995 \\
\hline & & Ghafori & 2.50 & .689 \\
\hline & & Hosseini & 1.75 & .892 \\
\hline & & Ghasemi & .10 & 1.000 \\
\hline & \multirow{4}{*}{ Ghafori } & Abdoulmaleki & -3.25 & .457 \\
\hline & & Ahari & -2.50 & .689 \\
\hline & & Hosseini & -.75 & .995 \\
\hline & & Ghasemi & -2.40 & .776 \\
\hline & \multirow{4}{*}{ Hosseini } & Abdoulmaleki & -2.50 & .704 \\
\hline & & Ahari & -1.75 & .892 \\
\hline & & Ghafori & .75 & .995 \\
\hline & & Ghasemi & -1.65 & .932 \\
\hline & \multirow{4}{*}{ Ghasemi } & Abdoulmaleki & -.85 & .994 \\
\hline & & Ahari & -.10 & 1.000 \\
\hline & & Ghafori & 2.40 & .776 \\
\hline & & Hosseini & 1.65 & .932 \\
\hline & & Ahari & 1.15 & .995 \\
\hline & & Ghafori & 2.02 & .956 \\
\hline & Abdoulmale & ${ }^{1}$ Hosseini & 5.40 & .329 \\
\hline & & Ghasemi & $-11.33^{*}$ & .003 \\
\hline & & Abdoulmaleki & -1.15 & .995 \\
\hline & Ahari & Ghafori & .88 & .998 \\
\hline & Anar1 & Hosseini & 4.25 & .559 \\
\hline & & Ghasemi & $-12.48^{*}$ & .001 \\
\hline & & Abdoulmaleki & -2.02 & .956 \\
\hline Ouestionskill & Ghafori & Ahari & -.88 & .998 \\
\hline Questionskill & Ghatori & Hosseini & 3.38 & .754 \\
\hline & & Ghasemi & $-13.35^{*}$ & .000 \\
\hline & & Abdoulmaleki & -5.40 & .329 \\
\hline & Hosceini & Ahari & -4.25 & .559 \\
\hline & Hossein1 & Ghafori & -3.38 & .754 \\
\hline & & Ghasemi & $-16.73^{*}$ & .000 \\
\hline & & Abdoulmaleki & $11.33^{*}$ & .003 \\
\hline & Ghasemi & Ahari & $12.48^{*}$ & .001 \\
\hline & Onasemi & Ghafori & $13.35^{*}$ & .000 \\
\hline & & Hosseini & $16.73^{*}$ & .000 \\
\hline & & Ahari & -.68 & .945 \\
\hline Teachinmethod & Abdoulmaleki & Ghafori & -.18 & 1.000 \\
\hline 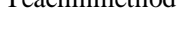 & Aovounta & Hosseini & .88 & .871 \\
\hline & & Ghasemi & -.68 & .958 \\
\hline
\end{tabular}




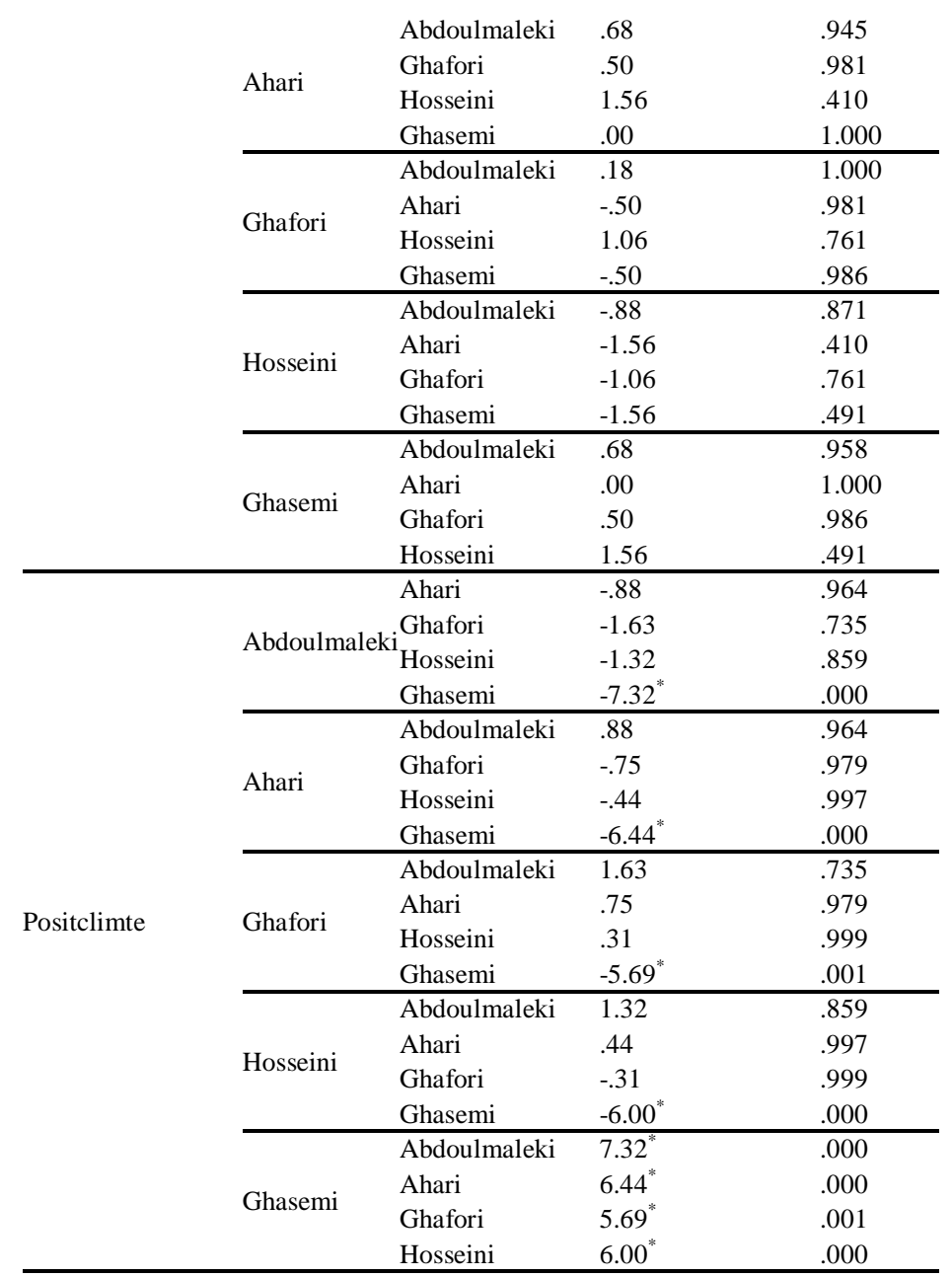

\section{Maintaining Focus and Attention.}

Based on the results displayed in tables 5, 6 and 7, there were significant differences between the five teachers' maintenance of focus and attention $\left(\mathrm{F}(4,70)=2.89, \mathrm{P}<.05\right.$, Partial $\eta^{2}=.14$ representing a large effect size). The means cores in order of magnitude were; Ghasemi $(M=24.61)$, Abdoulmaleki $(M=24.61)$, Ghafori $(M=23.28)$, Ahari $(\mathrm{M}=19.95)$ and Hosseini $(\mathrm{M}=19.91)$. Although the $\mathrm{F}$-value of 2.89 was significant, the results of the post-hoc Scheffe's tests did not show any significant differences between any two teachers. These results might seem contradictory, but the error rate inflates when running multiple comparisons.

Providing Students with Review and Practice.

Based on the results displayed in table 5, 6 and 7, there were not any significant differences between the five teachers' provision of review and practice $\left(\mathrm{F}(4,70)=1.27, \mathrm{P}>.05\right.$, Partial $\eta^{2}=.068$ representing a moderate effect size). The means cores in order of magnitude were; Abdoulmaleki $(M=19.93)$, Ahari $(M=19.18)$, Ghasemi $(M=$ 19.08), Hosseini ( $\mathrm{M}=17.43)$ and Ghafori $(\mathrm{M}=16.66)$.

Demonstrating Skills in Questioning.

Based on the results displayed in tables 5, 6, and 7, there were significant differences between the five teachers' demonstration of questioning skills $\left(\mathrm{F}(4,70)=10.91, \mathrm{P}<.05\right.$, Partial $\eta^{2}=.38$ representing a large effect size $)$. The means cores in order of magnitude were; Ghasemi $(M=45.66)$, Abdoulmaleki $(M=34.33)$, Ahari $(M=33.18)$, Ghafori $(\mathrm{M}=32.31)$ and Hosseini $(\mathrm{M}=28.93)$. The results of the post-hoc Scheffe's tests indicated that there were four significantly differences between the means. Ghasemi $(M=45.68)$ showed a significantly higher mean on demonstration of questioning skills than Abdoulmaleki $(\mathrm{M}=34.33)(\mathrm{MD}=11.33, \mathrm{P}<.05)$, Ghafori $(\mathrm{M}=32.31)(\mathrm{MD}=$ $12.48, \mathrm{P}<.05)$, Ahari $(\mathrm{M}=33.18)(\mathrm{MD}=12.48)$ and Hosseini $(\mathrm{M}=28.93)(\mathrm{MD}=16.73, \mathrm{P}<.05)$, did.

Demonstrating a Variety of Teaching Methods.

Based on the results displayed in tables 5,6,and 7, there were not any significant differences between the five teachers' demonstration of variety of teaching methods $\left(\mathrm{F}(4,70)=1.29, \mathrm{P}>.05\right.$, Partial $\eta^{2}=.069$ representing a moderate effect size). The means cores in order of magnitude were; Ghasemi and Ahari $(\mathrm{M}=8.75)$, Ghafouri $(\mathrm{M}=8.17)$, Abdoulmaleki $(\mathrm{M}=8.06)$ and Hosseini $(\mathrm{M}=7.18)$, did.

Establishing a Positive Climate.

Based on the results displayed in tables 5,6, and 7, there were significant differences between the five teachers' establishment of a positive climate $\left(F(4,70)=10.44, \mathrm{P}<.05\right.$, Partial $\eta^{2}=.37$ representing a large effect size). The 
means cores in order of magnitude were; Ghasemi $(M=22.25)$, Ghafori $(M=16.56)$, Hosseini $(M=16.25), A h a r i(M=$ 15.81) and Abdoulmaleki $(M=14.93)$. The results of the post-hoc Scheffe's tests indicated that there were four significantly differences between the means. Ghasemi $(M=22.25)$ showed a significantly higher mean on establishing a positive climate than Abdoulmaleki $(\mathrm{M}=14.93)(\mathrm{MD}=7.32, \mathrm{P}<.05)$, Ahari $(\mathrm{M}=15.81)(\mathrm{MD}=6.44, \mathrm{P}<.05)$, Ghafori $(M=16.56)(M=5.69)$ and Hosseini $(M=16.25)(M=6, P<.05)$, did.

\section{B. Investigation of the Research Question Two}

Data normality check.

First, the respective data were checked in terms of the normality assumption. As displayed in Table 8 , all of the values are below their respective critical values $( \pm 1.96)$; an indication of data normality. The homogeneity of variances was also checked to be discussed when reporting the results of the inferential statistics.

Testing Assumptions.

TABLE. 8.

ASSESSMENT OF NORMALITY

\begin{tabular}{|c|c|c|c|c|}
\hline Variable & skew & c.r. & kurtosis & c.r. \\
\hline NELSON & .935 & 6.691 & 1.663 & 5.950 \\
\hline Posttest & -.272 & -1.944 & -.800 & -2.860 \\
\hline Pretest & -.582 & -4.163 & -.490 & -1.753 \\
\hline Multivariate & & & .518 & .828 \\
\hline
\end{tabular}

Parametrically, the entry behaviors of the students as measured by both NELSON and Diagnostic Test showed nonsignificant different as shown in tables 8 and 9.

TABLE. 9.

INDEPENDENT SAMPLE TEST; NELSON BY GROUPS

\begin{tabular}{|c|c|c|c|c|c|c|c|c|c|}
\hline & \multicolumn{2}{|c|}{$\begin{array}{l}\text { Levene's Test for Equality } \\
\text { of Variances }\end{array}$} & \multicolumn{7}{|c|}{ t-test for Equality of Means } \\
\hline & \multirow[t]{2}{*}{$\mathrm{F}$} & \multirow[t]{2}{*}{ Sig. } & \multirow[t]{2}{*}{$\mathrm{T}$} & \multirow[t]{2}{*}{ df } & \multirow{2}{*}{$\begin{array}{l}\text { Sig. (2- } \\
\text { tailed) }\end{array}$} & \multirow{2}{*}{$\begin{array}{l}\text { Mean } \\
\text { Difference }\end{array}$} & \multirow{2}{*}{$\begin{array}{l}\text { Std. Error } \\
\text { Difference }\end{array}$} & \multicolumn{2}{|c|}{$\begin{array}{l}\text { 95\% Confidence Interval of } \\
\text { the Difference }\end{array}$} \\
\hline & & & & & & & & Lower & Upper \\
\hline $\begin{array}{l}\text { Equal variances } \\
\text { assumed }\end{array}$ & .208 & .648 & 1.346 & 305 & .179 & .948 & .704 & -.437 & 2.332 \\
\hline $\begin{array}{l}\text { Equal variances not } \\
\text { assumed }\end{array}$ & & & 1.347 & 304.859 & .179 & .948 & .704 & -.437 & 2.332 \\
\hline
\end{tabular}

TABLE 10

INDEPENDENT SAMPLES TEST; DIAGNOSTIC TEST BY GROUPS

\begin{tabular}{|c|c|c|c|c|c|c|c|c|}
\hline & \multicolumn{2}{|c|}{$\begin{array}{l}\text { Levene's Test for Equality of } \\
\text { Variances }\end{array}$} & \multicolumn{6}{|c|}{ t-test for Equality of Means } \\
\hline & \multirow[t]{2}{*}{$\mathrm{F}$} & \multirow[t]{2}{*}{ Sig. } & \multirow[t]{2}{*}{ Df } & \multirow{2}{*}{$\begin{array}{l}\text { Sig. }(2- \\
\text { tailed })\end{array}$} & \multirow{2}{*}{$\begin{array}{l}\text { Mean } \\
\text { Difference }\end{array}$} & \multirow{2}{*}{$\begin{array}{l}\text { Std. Error } \\
\text { Difference }\end{array}$} & \multicolumn{2}{|c|}{$\begin{array}{l}\text { 95\% Confidence Interval of the } \\
\text { Difference }\end{array}$} \\
\hline & & & & & & & Lower & Upper \\
\hline $\begin{array}{l}\text { Equal variances } \\
\text { assumed }\end{array}$ & .349 & .555 & 1.180305 & .239 & .498 & .422 & -.332 & 1.328 \\
\hline $\begin{array}{l}\text { Equal variances not } \\
\text { assumed }\end{array}$ & & & 1.179301 & 3.239 & .498 & .422 & -.333 & 1.329 \\
\hline
\end{tabular}

\section{Investigation of the Research Question Two.}

Following the normality check, an independent t-test was run to compare the experimental and control groups' mean scores on the Academic Achievement Test. The experimental group $(\mathrm{M}=20.97, \mathrm{SD}=5.14)$ showed a higher mean than the control group $(\mathrm{M}=17.62, \mathrm{SD}=6.40)$ on the Achievements Test (Table, 11).

TABLE. 11.

DESCRIPTIVE STATISTICS; POSTTEST OF ACADEMIC ACHIEVEMENTS By GROUPS

\begin{tabular}{llllll}
\hline & Group & $\mathrm{N}$ & Mean & $\begin{array}{l}\text { Std. } \\
\text { Deviation }\end{array}$ & $\begin{array}{l}\text { Std. Error } \\
\text { Mean }\end{array}$ \\
\hline \multirow{2}{*}{ Achievement } & Experimental & 156 & 20.97 & 5.149 & .412 \\
& Control & 151 & 17.62 & 6.405 & .521 \\
\hline
\end{tabular}

The results of the independent $\mathrm{t}$-test $(\mathrm{t}(287)=5.04, \mathrm{P}<.05, \mathrm{R}=.28$ representing an almost moderate effect size $)$ (Table 12) indicated that there was a significant difference between the two groups' mean scores.. Thus, the second null-hypothesis was rejected. 
TABLE. 12.

INDEPENDENT SAMPLES TEST; ACADEMIC ACHIEVEMENTS BY GROUPS

\begin{tabular}{|c|c|c|c|c|c|c|c|c|c|}
\hline & \multicolumn{2}{|c|}{$\begin{array}{l}\text { Levene's Test for Equality of } \\
\text { Variances }\end{array}$} & \multicolumn{7}{|c|}{ t-test for Equality of Means } \\
\hline & \multirow[t]{2}{*}{$\mathrm{F}$} & \multirow[t]{2}{*}{ Sig. } & \multirow[t]{2}{*}{$\mathrm{T}$} & \multirow[t]{2}{*}{ Df } & \multirow{2}{*}{$\begin{array}{l}\text { Sig. }(2- \\
\text { tailed) }\end{array}$} & \multirow{2}{*}{$\begin{array}{l}\text { Mean } \\
\text { Difference }\end{array}$} & \multirow{2}{*}{$\begin{array}{l}\text { Std. Error } \\
\text { Difference }\end{array}$} & \multicolumn{2}{|c|}{$\begin{array}{l}\text { 95\% Confidence Interval of the } \\
\text { Difference }\end{array}$} \\
\hline & & & & & & & & Lower & Upper \\
\hline $\begin{array}{l}\text { Equal variances } \\
\text { assumed }\end{array}$ & 13.392 & .000 & 5.0 & 51305 & .000 & 3.352 & .662 & 2.049 & 4.655 \\
\hline $\begin{array}{l}\text { Equal variances not } \\
\text { assumed }\end{array}$ & & & \multicolumn{3}{|c|}{5.044287 .500 .000} & 3.352 & .665 & 2.044 & 4.660 \\
\hline
\end{tabular}

The assumptions of homogeneity of variances were not met (Levene's $\mathrm{F}=13.39, \mathrm{P}<.05$ ). That is why the second row of Table 12, i.e. "Equal variances not assumed" is reported.

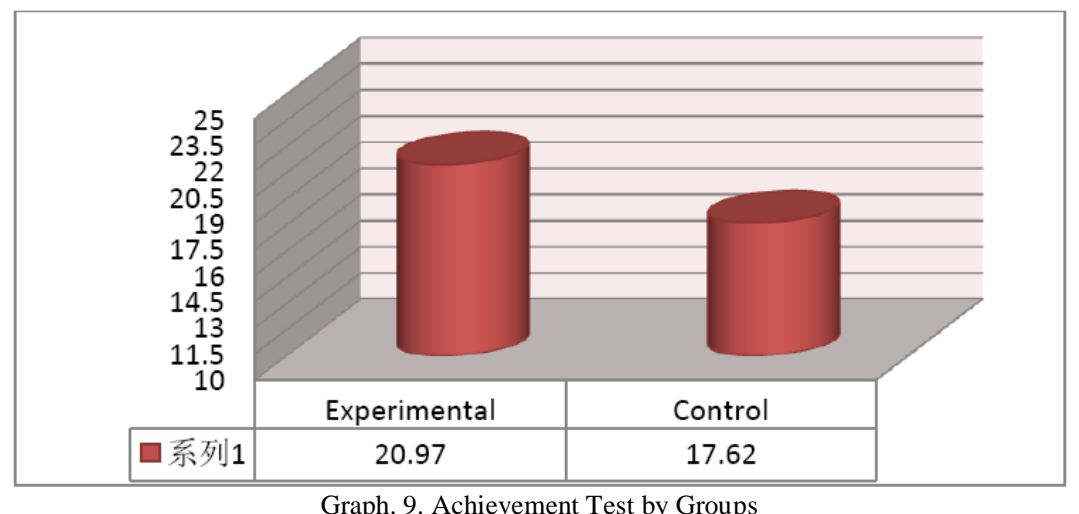

The result showed a significant change in achievement Test score of students due to the peer coaching, which is consistent with Richards' (2003), Sunderman \& Kim's (2007), Valenzuela, Prieto, \& Hamilton's (2007) and Prince, Snowden \& Matthews'(2010) studies on the positive effects of peer coaching on academic achievement.

Resultant to the peer coaching, the teachers showed the highest mean score on questioning skills, focus and attention, and review and practice. However, it did not have significant effect on the teaching skills and maintaining appropriate classroom behavior. Many findings, as supported by the findings of this study, have illustrated positive impact of coaching on classroom instruction (Kretlow, Cooke, \& Wood, 2012; Kretlow, Wood, \& Cooke, 2011; Capizzi, Wehby, \& Sandme, 2010; Newman \& Cunninghan, 2009; Landry, Anthony, Swank, \& Monseque-Bailey, 2009; Landry, 2010), and curriculum implementation (Caverly, Vaden-Kiernan, \& Fong, 2010; Spencer \& Logan, 2003). Totally, the findings of this study are in consistent with related researches that focused on effect of peer coaching on students as well as teachers (Garet et al., 2008, 2011; Elmore, 2002; Little, 2001; Elmore, 2002; Scher \& O'Reily, 2009; Kohler et al., 1997). However, Neufeld and Rope (2003) opposed positive effects of coaching on academic achievements as Garet et al. $(2008,2011)$ claimed so as to the professional development.

Investigating the effect of peer coaching on professional identity was an important step to help teachers to work cooperatively and also share their knowledge. Then, theoretically the findings contribute to the literature differently since they are revealing in two terms: teachers' professional development change on one hand and learners' academic achievements on the other, which bear promising pedagogical messages for teacher's self-development as well as others' development; their students.

\section{REFERENCES}

[1] Ackland, R. (1991). A review of the peer coaching literature. The Journal of Staff Development, 12(1), $22-27$.

[2] Beglau, M., Craig Hare, J., Foltos, L., Gann, K., James, J., Jobe, H., Knight, J., \& Smith, B. (2011). Technology, coaching, and community: Power partners for improved professional development in primary and secondary education (White Paper). Retrieved from International Society for Technology in Education website: http://iste.org.

[3] Beijaard, D., Verloop, N., \& Vermunt, J. (2000). Teachers' perceptions of identity. Teachers and Teaching: Theory and Practice, 1, 281-294.

[4] Beijaard, D., Meijer, P. C., \& Verloop, N. (2004). Reconsidering research on teachers' professional identity. Teaching and Teacher Education, 20(2), 107-128.

[5] Britton, R. L. (2006). The examination of the effects of peer coaching on the practices of pre-service teachers (Master's thesis). Retrieved from http://www.libres.uncg.edu/ir/uncw/f/brittonl 2006-1.pdf.

[6] Briton, R. L., \& Anderson, A. K. (2010). Peer coaching and pre-service teachers: examining and underutilized concept. Teaching and Teacher Education, 26(2), 306-314.

[7] Capizzi, A., Wehby, J., \& Sandme, K. N. (2010). Enhancing mentoring of teacher candidates through consultative feedback and self-evaluation of instructional delivery. Teacher Education and Special Education, 33(3), 191-212. 
[8] Caverly, S., Vaden-Kiernan, M., \& Fong, C. (2010). Bright Futures: Early Reading First Year Three Summary Evaluation Report. Austin, TX: Advancing Research Improving Education.

[9] Clandinin, D. J., \& Connelly, F. M. (1996) .Teachers' professional knowledge landscapes: Teacher stories-stories of teachersschool stories-stories of schools. Educational Researcher, 25(3), 24-30.

[10] Clarke, M., Hyde, A., \& Drennan, J. (2013). Professional identity in higher education. The Changing Academy - The Changing Academic Profession in International Comparative Perspective , 5, 7-21.

[11] Cochran-Smith, M., \& Lytle, S. L. (2001). Beyond certainty: Taking an inquiry stance on practice. In A. Lieberman, \& L. Miller (Eds.), Teachers caught in the action: Professional development that matters (pp. 45-58). New York: Teachers College Press.

[12] Cornett, J., \& Knight, J. (2009). Research on coaching. In J. Knight (Ed.), Coaching: Approaches \& Perspectives (pp. 192-216). Thousand Oaks, CA: Corwin Press.

[13] Costa, A. \& Garmston, B. (2002). Overview of cognitive coaching. Retrieved from http://www.cognitivecoaching.com/overview.htm.

[14] Devos, A. (2010). New teachers, mentoring and the discursive formation of professional identity. Teaching and Teacher Education, 26(5), 1219-1223.

[15] Elmore, R. (2002). Bridging the gap between standards and achievement: The imperative for professional development in education. Washington, D.C.: The Albert Shanker Institute.

[16] Epstein, A. (1978). Ethos and identity. Tavistock: London.

[17] Filed, A. (2013). Discovering statistics using IBM SPSS, statistics for statistics. London: SAGE Publications

[18] Fielding, M., Bragg, S., Craig, D., Cunningham, I., Eraut, M., Gillinson, S., Horne, M., Robinson, C., \& Thorp, J. (2005). Factors Influencing the Transfer of Good Practice. (Report No. RR615). University of Sussex \& Demos: Department for Education and Skills.

[19] Galbraith, P., \& Anstrom, K. (1995). Peer coaching: an effective staff development model for educators of linguistically and culturally diverse students. Directions in Language \& Education, 1(3), 694-701.

[20] Garet, M. S., Porter, A. C., Desimone, L., Birman, B. E., \& Yoon, K. S. (2001). What makes professional development effective? Results from a national sample of teachers. American Educational Research Journal, 38(4), 915-946.

[21] Garet, M. S., Wayne, A. J., Stancavage, F., Taylor, J., Eaton, M., Walters, K., Song, M., Brown, S., Hurlburt, S., Zhu, P., Sepanik, S., \& Doolittle, F. (2011). Middle school mathematics professional development impact study: Findings after the second year of implementation. Washington, D. C.: U.S. Department of Education, National Center for Education Statistics.

[22] Huston, T. \& Weaver, C. (2008). Peer Coaching: Professional Development for Experienced Faculty. Journal of Innovation in Higher Education, 33, 5- 20.

[23] Korthagen, F. A. J. (2004). In search of the essence of a good teacher: Towards a more holistic approach in teacher education. Teaching and Teacher Education, 20(1), 77-97.

[24] Kretlow, A., Cooke, N., \& C. Wood. (2012). Using in-service and coaching to increase teachers' accurate use of research-based strategies. Journal of Special Education, 33(6), 348-361.

[25] Kretlow, A., Wood, C., \& Cooke, N. (2011). Using in-service and coaching to increase kindergarten teachers' accurate delivery of group instructional units. Journal of Special Education, 44(4), 234.

[26] Ladyshewsky, R. K. (2006). Building cooperation in peer coaching relationships: understanding the relationships between reward structure, learner preparedness, coaching skill and learner engagement. ELSEVIER, 92, 4-10. doi:10.1016/j.physio.2005.11.005

[27] Landry, S. (2010, November). Advancing quality school readiness programs in early childhood through systematic change. Paper presented at the NCRECE Leadership Symposium, Washington, DC.

[28] Landry, S. H., Anthony, J. L., Swank, P. R., \& Monseque-Bailey, P. (2009). Effectiveness of comprehensive professional development for teachers of at-risk preschoolers. Journal of Educational Psychology, 101(2), 448-465.

[29] Lasky, S. (2005). A sociocultural approach to understanding teacher identity, agency and professional vulnerability in a context of secondary school reform. Teaching and Teacher Education, 21(8), 899-916.

[30] Little, J. (2001). Professional development in the pursuit of school reform. In A. Lieberman, \&L. Miller (Eds.), Teachers caught in the action (pp. 23-44). New York: Teachers College Press.

[31] Neubert, C. A., \& McAllister, E. (1993). Peer coaching in pre-service education. Teacher Education Quarterly, 20(4), 77-84.

[32] Neufeld, B., \& Roper, D. (2003a). Coaching: A strategy for developing instructional capacity. Providence, RI: Annenberg Institute for School Reform.

[33] Neufeld, B., \& Roper, D. (2003b). Year II of collaborative coaching and learning in the effective practice schools. Cambridge, MA: Education Matters.

[34] Newman, S. B. \& Cunningham, L. (2009). The impact of professional development and coaching on early language and literacy instructional practices. American Educational Research Journal, 46(2), 532-566.

[35] Odell, S. J. (1990). Mentor teacher programs: What research says to the teacher? Washington, D.C.: National Education Association.

[36] Perkins, S. J. (1998). On becoming a peer coach: Practices, identities, and beliefs of in experienced coaches. Journal of Curriculum and Supervision, 13(3), 235-254.

[37] Prince, T., Snowden, E., \& Matthews, B. (2010). Utilizing peer coaching as a tool to improve student-teacher confidence and support the development of classroom practice. Literacy Information and Computer Education Journal, 1(1), 45-51.

[38] Rainville, N. K. (2007). Situated identities, power, and positioning: inside the practices of three literacy coaches in New Jersey (Doctoral dissertation). Retrieved from http://www.literacycoachingonline.org.

[39] Reiman, A. J., \& Johnson, L. (2003).Promoting teacher professional judgment. Journal of Research in Education, 13(1), 4-14.

[40] Richard, A. (2003). Making our own way: The emergence of school-based staff developers in America's public schools. Retrieved from http://www.emcf.org/pdf/student_ourownroadbw.pdf. 
[41] Robertson, J. (2008). Coaching leadership: building educational leadership capacity through coaching partnerships. London: SAGE.

[42] Saphier, J., \& West, L. (2009). How coaches can maximize student learning. Phi Delta Kappan, 91(4), 46-50.

[43] Scher, L., \& O'Reilly, F. (2009). Professional development for K-12 math and science teachers: What do we really know? Journal of Research on Educational Effectiveness, 2(3), 209-249.

[44] Sherri, A. (2010). Coaching language teachers. CAL Digest. Retrieved from: www.cal.org/resources/digest/coachinglanguange-teachers.html.

[45] Showers, B. (1982). Transfer of training: The contribution of coaching. Eugene OR: Centre for Educational Policy and Management.

[46] Singh, G., \& Richards, J. C. (2006). Teaching and learning in the language teacher education course room: a critical sociocultural perspective. A Journal of Language Teaching and Research, 37(2), 149-175. doi: 10.1177/0033688206067426.

[47] Spencer, S. S., \& Logan, K. R. (2003). Bridging the Gap: A School Based Staff Development Model that Bridges the Gap from Research to Practice. Teacher Education and Special Education: The Journal of the Teacher Education Division of the Council for Exceptional Children, 26(1), 51-62.

[48] Sumner, Y. K. (2011). An explanatory mixed-methods study of instructional coaching practices and their relationship to student achievements (Doctoral dissertation). Retrieved fromhttp://libres.uncg.edu.

[49] Sunderman, G. L., \& Kim, J. S. (2007). The expansion of federal power and the politics of implementing the No Child Left Behind Act. Teachers College Record, 109(5), 1057-1085.

[50] Vakili, L. (2010). The Teacher Self Construction of Language Teachers (Unpublished doctoral dissertation). University of Exeter: UK.

[51] Valenzuela, A., Prieto, L., \& Hamilton, M. P. (2007). Introduction to the special issue: No Child Left Behind (NCLB) and minority youth: What the qualitative evidence suggests. Anthropology \& Education Quarterly, 38(1), 1-8.

[52] Wenger, E. (2008). Communities of practice: Learning, meaning and practice. New York: Cambridge University Press.

Gholam-Reza Abbasian, born in Ahar, East Azerbaijan, is an assistant professor of TEFL at Imam Ali and IA (South Tehran) universities, and has presented some papers at (inter) national conferences. He is the author and translator of about 15 books, and publisher of scholarly articles. Dr. Abbasian offers psycholinguistics, language testing, and research methods at MA and PhD levels. Nominated as top scholar and teacher for seven consecutive years, he is the internal manager of JOMM, reviewer of Sage, FLA and GJER journals and a member of editorial board of JSSIR.

Matin Karbalaee Esmailee, received her M.A. from Alborz Institute of Higher Education. She is a teacher in Jahad Farhangi institute and also works as translator. Esmailee has worked with various ages/levels of ESL learners ranging from beginning to advanced students. She enjoys teaching pronunciation, grammar, and listening/speaking with every subject and every skill level. Moreover, she has been teaching ESL for 11 years, including six years in Tarig Institute as both teacher and supervisor. Additionally, she really loves to help ESL students who are in need. 